\title{
Pengaruh servant leadership, komitmen organisasi, dan lingkungan fisik terhadap kinerja guru
}

\author{
Hendro Prasetyono *, Ira Pratiwi Ramdayana \\ Universitas Indraprasta PGRI. \\ Jl. Raya Tengah No. 80, Gedong, Jakarta Timur, Daerah Khusus Ibukota Jakarta 13760, Indonesia. \\ * Corresponding Author. E-mail: hendro prasetyono@unindra.ac.id
}

\section{ARTICLE INFO \\ Article History \\ Received: \\ 29 November 2019; \\ Revised: \\ 1 August 2020; \\ Accepted: \\ 5 August 2020 \\ Available online: \\ 25 September 2020}

\section{Keywords}

Kinerja guru;

Komitmen organisasi;

Lingkungan fisik;

Sekolah Menengah

Kejuruan (SMK);

Organizational

commitment;

Physical environment;

Servant leadership;

Teacher performance;

Vocational high

schools

\begin{abstract}
Tujuan dari penelitian ini adalah untuk mengetahui pengaruh servant leadership, komitmen organisasi dan lingkungan fisik secara bersama-sama terhadap kinerja guru, pengaruh servant leadership terhadap kinerja guru, komitmen organisasi terhadap kinerja guru, lingkungan kerja fisik terhadap kinerja guru. Metode penelitian yang digunakan adalah survey. Jumlah sampel 63 orang guru, teknik sampling yang digunakan yaitu cluster sampling yang diambil dari 3 Sekolah Menengah Kejuruan Negeri (SMK) di Kotamadya Jakarta Timur secara proporsional. Hasil penelitian: 1.) Terdapat pengaruh yang positif dan signifikan servant leadership, komitmen organisasi dan lingkungan kerja fisik secara bersama-sama terhadap kinerja guru; 2.) Terdapat pengaruh yang positif dan signifikan servant leadership terhadap kinerja; 3 .) Terdapat pengaruh yang positif dan signifikan komitmen organisasi terhadap kinerja guru; dan 4.) Tidak terdapat pengaruh yang positif dan signifikan lingkungan kerja fisik terhadap kinerja guru.
\end{abstract}

The purpose of this study was to determine the effect of servant leadership, organizational commitment, and the physical environment together on teacher performance, the influence of servant leadership on teacher performance, organizational commitment to teacher performance, physical work environment on teacher performance. The research method used was a survey. The total sample of 63 teachers, the sampling technique used is cluster sampling taken from 3 State Vocational High Schools in the Municipality of East Jakarta proportionally. Research results: 1.) There is a positive and significant influence of servant leadership, organizational commitment, and physical work environment together on teacher performance; 2.) There is a positive and significant influence of servant leadership on performance; 3.) There is a positive and significant influence of organizational commitment on teacher performance; and 4.) There is no positive and significant influence of the physical work environment on teacher performance.

This is an open access article under the CC-BY-SA license.

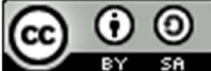

How to cite:

Prasetyono, H., \& Ramdayana, I. P. (2020). Pengaruh servant leadership, komitmen organisasi, dan lingkungan fisik terhadap kinerja guru. Jurnal Akuntabilitas Manajemen Pendidikan, 8(2), 108-123. doi: https://doi.org/10.21831/jamp.v8i1.28458 


\section{PENDAHULUAN}

Pertumbuhan jumlah Sekolah Mengengah Kejuruan (SMK) saat ini sangat pesat. Hal ini disebabkan karena tingginya permintaan dari masyarakat untuk mendirikan SMK dan perizinan pendirian SMK beberapa tahun terakhir masih dipegang oleh pemerintah kabupaten kota sehingga lebih mudah dalam perizinan (Pusriawan \& Soenarto, 2019). Namun kondisi ini belum diikuti oleh peningkatan dan pemerataan kualitas lulusan SMK. Lulusan SMK masih banyak yang menganggur terlihat dari angka pengangguran terbesar di Indonesia dihasilkan oleh para lulusan SMK yaitu $11,24 \%$ dibanding lulusan SMA yang hanya 7,9\%. Padahal jumlah lulusan SMK setiap tahun lebih sedikit dari lulusan SMA yang berjumlah 2,1 juta, lulusan SMK hanya sekitar 1,4 juta sehingga sistem pendidikan vokasi masih perlu dibenahi

Pemerintah telah melakukan beragam upaya untuk meningkatkan kualitas penyelenggaraan pendidikan di SMK. Hal ini terbukti dengan dikeluarkankanya instruksi Presiden Republik Indonesia Nomor 9 Tahun 2016 tentang Revitalisasi Sekolah Menengah Kejuruan (SMK) dan bekerjasama dengan Kementerian Perindustrian untuk meningkatkan kompetensi guru SMK (Darmawan, 2019). Kualitas penyelenggaraan pendidikan terutama di SMK diantaranya ditentukan oleh kinerja yang dihasilkan oleh guru (Susanto, 2012). Guru yang memiliki kinerja sesuai dengan standar pendidikan hampir dipastikan kualitas proses pembelajaran dikelas juga akan berkualitas (Kartowagiran, 2011). Oleh sebab itu, penting bagi para pengambil kebijakan untuk selalu memperhatikan beragam faktor yang berkontribusi terhadap kinerja guru agar dapat terjaga dan meningkat kinerjanya.

Kinerja guru adalah suatu perilaku yang dihasilkan seorang guru dalam melaksanakan tugasnya sebagai pendidik dan pengajar ketika mengajar di depan kelas (Nasrun, 2016). Kinerja guru akan terlihat pada situasi dan kondisi sehari-hari dalam mengajar di kelas. Kondisi tersebut tercermin pada aspek kegiatan dalam menjalankan tugas dan cara atau kualitas dalam melaksanakan tugas dan tanggungjawab sebagai seorang guru. Indikator kinerja guru menurut Warren dan Hale (2016) adalah kualitas kerja, kuantitas kerja, dan pemanfaatan waktu. Terdapat beragam faktor yang mempengaruhi kinerja guru, diantaranya adalah servant leadership, komitmen organisasi, dan lingkungan fisik (Arianto, 2013; Purwoko, 2018). Menurut Greenleaf (Eva, Robin, Sendjaya, van Dierendonck, \& Liden, 2019) servant leadership adalah seseorang yang menjadi pelayan lebih dahulu yang diawali dari perasaan alami bahwa seseorang yang ingin melayani, harus terlebih dulu melayani. Kemudian pilihan secara sadar membawa seseorang untuk memimpin.

Terdapat 10 karakteristik servant leadership, yaitu: 1.) Mendengarkan dengan penuh perhatian kepada orang lain; 2.) Berusaha memahami rekan kerja dan mampu berempati dengan orang lain; 3.) Mampu menciptakan penyembuhan emosional; 4.) Kesadaran untuk memahami isu-isu yang berkembang; 5.) Melihat situasi dari posisi yang seimbang; 6.) Meyakinkan orang lain daripada memaksa kepatuhan; 7.) Visioner dan teliti dalam memahami pelajaran dari masa lalu; 8.) Realitas saat ini, dan kemungkinan konsekuensi dari keputusan untuk masa depan, 9.) Terbuka; dan 10.) Komitmen untuk pertumbuhan dan membangun komunitas (Greasley \& Bocârnea, 2014). Jika diintisarikan dimensi servant leadership adalah altruistic calling, emotional healing, wisdom, persuasive mapping, organizational stewardship, humility, vision, dan service (Wahyu \& Lantu, 2014).

Setiap organisasi tak lepas sekolah selalu berupaya mencapai tujuan secara maksimal. Untuk mencapai tujuan tersebut, diperlukan pemimpin yang mampu mengendalikan organisasi dan mampu mempengaruhi orang-orang atau bawahan yang ada dalam organisasi agar bekerja dengan maksimal (Sinha \& Hanuscin, 2017). Dengan kata lain keberhasilan suatu organisasi dalam mencapai tujuan sangat tergantung pada gaya kepemimpinan yang diterapkan. Hubungan yang terjalin antara guru dan kepala sekolah sebagai pemimpin secara emosional dengan lembaga akan mendorong dan meningkatkan komitmen guru untuk tetap menjadi bagian dari organisasi tersebut (Cheng \& Szeto, 2016). Menurut Allen dan Meyer (dalam Suriansyah, 2014) menyatakan bahwa komitmen kepada organisasi didefinisikan sebagai kesediaan sikap pegawai untuk tetap berada pada organisasi secara dan hubungan dirinya dengan tujuan, nilai, dan kewajibannya dalam organisasi. Komitmen organisasi dianggap sebagai kekuatan relatif mengidentifikasi kepercayaan, keterlibatan, dan kepatuhan individu terhadap organisasinya (Choi \& Tang, 2009). Dimensi dari komitmen adalah komitmen afektif, komitmen berterusan dan komitmen normatif (Luthans, 2011). Komitmen afektif 
adalah sikap pegawai yang merasa bahwa hubungan dirinya dengan tujuan-tujuan organisasi adalah seiring atau sesuai dengan nilai-nilai yang ada pada dirinya (Huang, 2011). Oleh kerana itu, pegawai yang memiliki komitmen afektif yang tinggi akan tetap berada di dalam organisasi kerana dia memang menginginkannya.

Komitmen normatif adalah keinginan pegawai untuk tetap berada dalam organisasi karena sudah merupakan tugas dan kewajiban, pengabdian, atau kewajiban moral (Cheasakul \& Varma, 2016). Biasanya komitmen ini didorong oleh budaya individu dan etika kerja, yang menyebabkan pegawai merasa wajib untuk tetap berada di dalam sesebuah organisasi yang bersangkutan (Jo, 2014). Komitmen ini tidak menggambarkan keperluan yang terkait dengan tujuan atau misi organisasi. Guru yang memiliki komitmen normatif yang tinggi akan tetap berada di dalam sekolah karena merupakan kewajiban yang harus dijalaninya sesuai dengan norma atau nilai yang dianutnya.

Komitmen berterusan adalah ketika pegawai memiliki pertimbangan secara ekonomi bahwa dia harus tetap berada pada organisasi tersebut (Mohammadtaheri, 2011). Pertimbangan ini didasarkan pada dua alasan yaitu, 1.) Sebagai individu yang telah memperoleh masa kerja yang telah memberikan jaminan hari tua, sudah menjadi pegawai senior, kepakaran dan keahlian yang tidak dapat dipindah-pindah ke tempat lain, afiliasi lokal, ikatan keluarga, dan 2.) Seseorang merasa harus tetap berada di tempat kerjanya pada saat ini, karena dia tidak punya alternatif pekerjaan lain (Klassen $\&$ Chiu, 2011). Oleh sebab itu, guru dengan komitmen berterusan yang tinggi tetap berada dalam pekerjaannya, karena dia merasa pekerjaannya telah mapan bagi hidupnya atau karena dia tidak punya alternatif lain. Komitmen guru akan memperlancar aktivitas sekolah dalam mencapai tujuan pendidikan yang ditandai dengan terciptanya peningkatan kualitas lingkungan fisik maupun psikologis, sehingga segala sesuatunya menjadi menyenangkan bagi seluruh warga sekolah (Sumantri, 2012). Dengan kata lain komitmen kerja guru yang tinggi salah satu didapatkan dari lingkungan kerja fisik di sekolah.

Teori lingkungan kerja adalah lingkungan fisik tempat karyawan bekerja yang mempengaruhi kinerja, keamanan, dan mutu kehidupan kerja mereka. Lingkungan kerja yang kondusif memberikan rasa aman dan memungkinkan para pegawai untuk dapat bekerja secara optimal (Smantser \& Ignatovitch, 2015). Lingkungan kerja tersebut mencakup hubungan kerja yang terbentuk antara sesama pegawai dan hubungan kerja antar bawahan dan atasan serta lingkungan fisik tempat pegawai bekerja (Fernet, Trépanier, Austin, \& Levesque-Côté, 2016). Lingkungan kerja fisik sangat mempengaruhi tingkah laku manusia dalam beraktifitas. Lingkungan kerja fisik mempengaruhi semangat dan emosi kerja para karyawan saat bekerja. Guru akan lebih termotivasi dan betah untuk bekerja di sekolah jika lingkungan kerja yang aman dan nyaman. Faktor-faktor fisik ini mencakup suhu udara di tempat kerja, luas ruang kerja, kebisingan, kepadatan, dan kesesakan (Pramana \& Sudharma, 2013).

Menurut Wursanto (dalam Suwondo \& Sutanto, 2015), indikator lingkungan kerja fisik merupakan segala sesuatu yang menyangkut segi fisik dalam lingkungan kerja. Bentuk fisik lingkungan kerja yang baik meliputi penerangan yang cukup, tempat yang bersih, tersedianya alat-alat pengaman, sirkulasi udara yang baik, suara bising yang dapat ditekan seminimal mungkin, tersedianya fasilitas pendukung lainnya, dan adanya fasilitas-fasilitas yang diberikan perusahaan. Berdasarkan hasil studi pendahuluan yang dilakukan oleh penulis pada 3 SMK Negeri di Jakarta Timur, para guru di sekolah tersebut masih perlu meningkatkan kinerja agar lebih optimal. Masih perlu peningkatan dalam hal kreativitas mengajar, pemanfataan waktu, dan pemanfaatan media pembelajaran. Temuan ini diperkuat oleh hasil penelitian Tokhibin dan Wuradji (2013) yang menyatakan bahwa guru harus meningkatkan kinerjanya untuk dapat menghasilkan lulusan yang lebih berkualitas.

Berdasarkan fenomena tersebut perlu dikaji secara cermat, mengapa para guru belum dapat menunjukkan kinerja yang tinggi padahal sekolah adalah suatu lembaga pendidikan yang berperan sentral dalam mencetak generasi bangsa yang unggul. Selain itu jika dilihat dari latar belakang pendidikan, pengalaman, masa kerja, sudah cukup memadai sesuai dengan bidang pekerjaannya. Salah satu ciri krisis pendidikan di Indonesia adalah guru belum mampu menunjukkan kinerja yang memadai (Hasanah, Fattah, \& Prihatin, 2010). Hal ini berarti kinerja guru mempengaruhi kualitas pendidikan. Fenomena ini harus segera ditanggulangi untuk dapat meningkatkan kualitas pendidikan di Indonesia. 


\section{METODE}

Pendekatan penelitian adalah kuantitatif dengan metode metode survei karena berusaha membuktikan hipotesis pengaruh variabel bebas terhadap variabel terikat (Singh, 2007). Variabel eksogen terdiri dari variabel $\mathrm{X}_{1}, \mathrm{X}_{2}$ dan $\mathrm{X}_{3}$. Seluruh variabel tersebut memberikan pengaruh langsung dan secara sendiri-sendiri terhadap variabel endogen (Y). Penelitian dilakukan pada 3 Sekolah Menengah Kejuruan Negeri di Kecamatan Cipayung Jakarta Timur, yaitu SMK Negeri 46, SMK Negeri 50, dan SMK Negeri 26. Teknik pengambilan sampel menggunakan metode kuota sampling dimana pengambilan jumlah sampel berdasarkan kuota tergantung jumlah populasi pada setiap lokasi (Gorard, 2004). Jumlah sampel dihitung menggunakan rumus Slovin dengan taraf kesalahan 10\% kemudian dihitung secara proporsi berdasarkan setiap jumlah populasi setiap sekolah (Dattalo, 2008). Jumlah sampel yang didapat berjumlah 63 orang dari total 173 guru dari 3 sekolah tersebut dengan penghitungan yang dapat dilihat pada Tabel 1.

Tabel 1. Jumlah Sampel

\begin{tabular}{cccc}
\hline Nama Sekolah & Jumlah Guru & Proporsi & Jumlah Sampel \\
\hline SMKN 46 & 41 & $41 / 173 * 63$ & 15 \\
SMKN 50 & 42 & $42 / 173 * 63$ & 15 \\
SMKN 26 & 90 & $90 / 173 * 63$ & 33 \\
& Jumlah & & 63 \\
\hline
\end{tabular}

Sumber: http://datapokok.ditpsmk.net/

Penyusunan kuesioner berdasarkan pada kisi-kisi instrumen yang berasal dari indikator setiap variabel dalam penelitian ini. Adapun kisi-kisi instrumen variabel kinerja dapat dilihat pada Tabel 2.

Tabel 2. Kisi-Kisi Variabel Kerja

\begin{tabular}{clcc}
\hline No. & & Indikator & Jumlah \\
\hline 1 & Kualitas Kerja & & 8 \\
2 & Kuantitas Kerja & & 10 \\
3 & Pemanfataan Waktu & & 4 \\
& & Jumlah & 22 \\
\hline
\end{tabular}

Setelah kuesioner disusun kemudian diuji validitas dan reliabilitas terhadap 20 orang responden. Setelah diuji ternyata ada 2 butir yang tidak valid sehingga tersisa 20 butir pernyataan yang valid. Butir instrumen yang telah dinyatakan valid tersebut kemudian dihitung realibilitasnya dan menghasilkan koefesien alpha (alpha cronbach) sebesar 0,77 yang berarti reliabel. Kisi-kisi instrumen variabel servant leadership dapat dilihat pada Tabel 3.

Tabel 3. Kisi-Kisi Variabel Servant Leadership $\left(\mathrm{X}_{1}\right)$

\begin{tabular}{|c|c|c|}
\hline No. & Indikator & Jumlah butir \\
\hline 1 & $\begin{array}{l}\text { Altruistic calling } \\
\text { Fmotional healing and wisisdom }\end{array}$ & 4 \\
\hline 2 & Emotional healing and wisisdom & 5 \\
\hline 3 & Persuasive mapping & 5 \\
\hline 4 & Organizational stewardship and humility & 5 \\
\hline \multirow[t]{2}{*}{5} & Vision and service & 6 \\
\hline & Jumlah & 25 \\
\hline
\end{tabular}

Setelah kuesioner disusun kemudian diuji validitas dan reliabilitas terhadap 20 orang responden. Setelah diuji ternyata ada 5 butir yang tidak valid sehingga tersisa 20 butir pernyataan yang valid. Butir instrumen yang telah dinyatakan valid tersebut kemudian dihitung realibilitasnya 
dan menghasilkan koefesien alpha (alpha cronbach) sebesar 0,81 yang berarti sangat reliabel. Kisikisi instrumen variabel komitmen organisasi dapat dilihat pada tabel 4 .

Tabel 4. Kisi-Kisi Variabel Komitmen Organisasi $\left(\mathrm{X}_{2}\right)$

\begin{tabular}{|c|c|c|}
\hline No. & Indikator & Jumlah \\
\hline 1. & Komitmen afektif & 8 \\
\hline 2. & Komitmen berterusan & 8 \\
\hline 3. & Komitmen normatif & 7 \\
\hline & Jumlah & 23 \\
\hline
\end{tabular}

Setelah kuesioner disusun kemudian diuji validitas dan reliabilitas terhadap 20 orang responden. Setelah diuji ternyata ada 4 butir yang tidak valid sehingga tersisa 19 butir pernyataan yang valid. Butir instrumen yang telah dinyatakan valid tersebut kemudian dihitung realibilitasnya dan menghasilkan koefesien alpha (alpha cronbach) sebesar 0,88 yang berarti sangat reliabel. Kisikisi instrumen variabel lingkungan fisik dapat dilihat pada Tabel 5.

Tabel 5. Kisi-Kisi Variabel Lingkungan Fisik $\left(\mathrm{X}_{3}\right)$

\begin{tabular}{|c|c|c|}
\hline No & Indikator & Jumlah \\
\hline 1 & Kondisi sarana kerja & 5 \\
\hline 2 & Prasarana kerja & 6 \\
\hline 3 & Kondisi Administrasi & 5 \\
\hline 4 & Kondisi Tempat Kerja & 5 \\
\hline & Jumlah & 21 \\
\hline
\end{tabular}

Setelah kuesioner disusun kemudian diuji validitas dan reliabilitas terhadap 20 orang responden. Setelah diuji ternyata ada 2 butir yang tidak valid sehingga tersisa 19 butir pernyataan yang valid. Butir instrumen yang telah dinyatakan valid tersebut kemudian dihitung realibilitasnya dan menghasilkan koefesien alpha (alpha cronbach) sebesar 0,84 yang berarti sangat reliabel. Teknik analisis data menggunakan korelasi, regrasi dan uji $\mathrm{F}$ untuk uji hipotesis dengan berbantu software SPSS 24 untuk mengetahui besarnya pengaruh setiap variabel bebas terhadap variabel terikat baik secara parsial mapupun simultan. Hipotesis penelitian adalah sebagai berikut:

$\mathrm{H}_{1}$ : Pengaruh yang positif dan signifikan servant leadership, komitmen organisasi dan lingkungan fisik secara bersama-sama terhadap kinerja guru.

$\mathrm{H}_{2}$ : Pengaruh yang positif dan signifikan servant leadership terhadap kinerja guru.

$\mathrm{H}_{3}$ : Pengaruh yang positif dan signifikan komitmen organisasi terhadap kinerja guru.

$\mathrm{H}_{4}$ : Pengaruh yang positif dan signifikan lingkungan fisik terhadap kinerja guru

\section{HASIL DAN PEMBAHASAN}

Hasil

Proses perhitungan diawali dengan menghitung pengaruh seluruh variabel $\mathrm{X}$ terhadap variabel $\mathrm{Y}$ kemudian dilanjutkan dengan menghitung uji signifikan model regresi, menghitung persamaan regresi, dan besarnya koefisien korelasi setiap variabel $\mathrm{X}$ terhadap variabel $\mathrm{Y}$, kemudian diakhiri dengan uji hipotesis. Hasil penghitungan pengaruh seluruh variabel $\mathrm{X}$ terhadap variabel $\mathrm{Y}$ dapat dilihat pada Tabel 6 . Berdasarkan Tabel 6 menampilkan nilai $\mathrm{R}$ sebesar 0,731 dan $\mathrm{R}_{\text {Square }}$ sebesar 0,535. Angka ini menunjukkan bahwa kinerja guru (Y) dipengaruhi oleh servant leadership $\left(X_{1}\right)$, komitmen organisasi $\left(X_{2}\right)$, dan lingkungan fisik $\left(X_{3}\right)$ sebesar $53,5 \%$, dan sisanya $46,5 \%$ dipengaruhi oleh variabel lain yang tidak diteliti dalam penelitian ini. Hasil penghitungan uji signifikansi model regresi dapat dilihat pada Tabel 7. 
Tabel 6. Hasil Perhitungan Pengujian Koefisien Korelasi Ganda Variabel $\mathrm{X}_{1}, \mathrm{X}_{2}$, dan $\mathrm{X}_{3}$ terhadap $\mathrm{Y}$

\begin{tabular}{ccccccccccc}
\hline & & & & & \multicolumn{4}{c}{ Change Statistics } \\
\cline { 6 - 10 } Model & $\mathrm{R}$ & $\mathrm{R}_{\text {Square }}$ & $\begin{array}{c}\text { Adjusted } \\
\mathrm{R}_{\text {Square }}\end{array}$ & $\begin{array}{c}\text { Std. Error of } \\
\text { the Estimate }\end{array}$ & $\begin{array}{c}\mathrm{R}_{\text {Square }} \\
\text { Change }\end{array}$ & F Change & df1 & df2 & $\begin{array}{c}\text { Sig. F } \\
\text { Change }\end{array}$ \\
\hline 1 & & $.731^{\mathrm{a}}$ & .535 & .511 & 7.186 & .535 & 22.618 & 3 & 59 & .000 \\
\hline
\end{tabular}

a. Predictors: (Constant), lingkungan fisik, komitmen organisasi, servant leadership

b. Dependent Variabel: Kinerja guru

Tabel 7. Hasil Perhitungan Pengujian Signifikansi Koefisien Regresi Variabel $\mathrm{X}_{1}, \mathrm{X}_{2}$, dan $\mathrm{X}_{3}$ terhadap Y

\begin{tabular}{llccccc}
\hline \multicolumn{1}{c}{ Model } & Sum of Squares & df & Mean Square & F & Sig. \\
\hline Regression & 3504.351 & 3 & 1168.117 & 22.618 & $.000^{\mathrm{b}}$ \\
1 & Residual & 3047.078 & 59 & 51.645 & & \\
\cline { 2 - 5 } & Total & 6551.429 & 62 & & & \\
\hline
\end{tabular}

a. Dependent Variabel: Kinerja guru

b. Predictors: (Constant), lingkungan fisik, komitmen organisasi, servant leadership

Berdasarkan pada Tabel 7 diperoleh nilai F sebesar 22,618 dengan tingkat probabilitas Sig. 0,000 . Oleh karena nilai Sig $<0,05$ maka model regresi ganda dapat dipakai untuk memprediksi kinerja guru. Hasil penghitungan persamaan regresi dapat dilihat pada Tabel 8.

Tabel 8. Hasil Perhitungan Persamaan Regresi Ganda Variabel $\mathrm{X}_{1}, \mathrm{X}_{2}$, dan $\mathrm{X}_{3}$ terhadap $\mathrm{Y}$

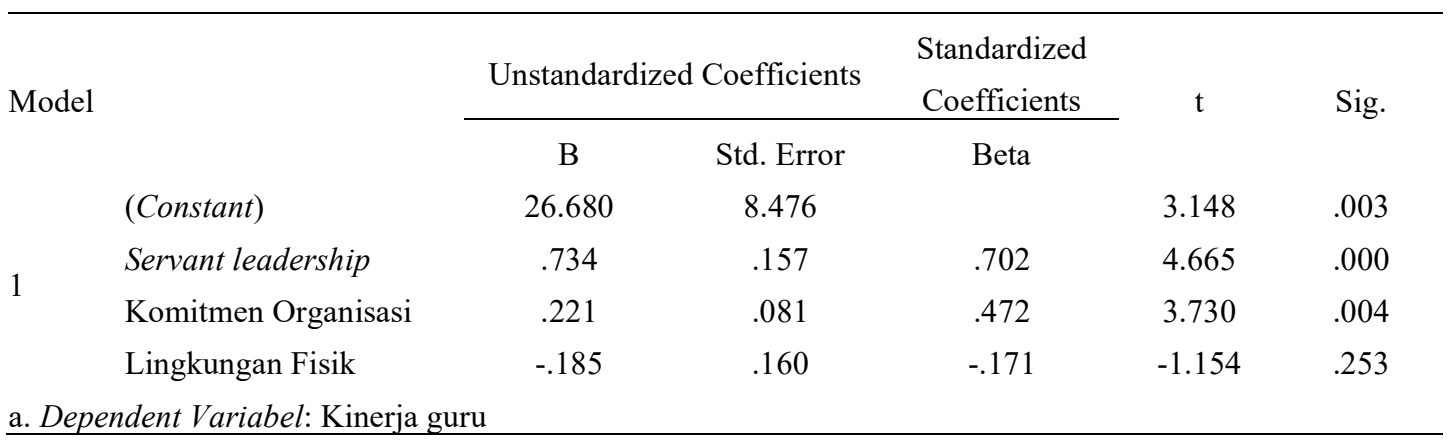

Berdasarkan pada Tabel 8 diketahui nilai konstanta (a) sebesar 26,68; nilai B sebesar 0,734; nilai $C$ sebesar 0,211 ; dan nilai t hitung 4,665. Maka diperoleh persamaan perhitungan regresi yaitu $\hat{Y}=26,68+0,734 X_{1}+0,211 X_{2}-0,185 X_{3}$. Persamaan regresi tersebut memiliki makna jika tidak ada perubahan servant leadership, komitmen organisasi dan lingkungan fisik maka besarnya kinerja guru adalah 26,68. Koefisien regresi sebesar 0,734 menyatakan bahwa setiap penambahan servant leadership sebesar 0,734 akan meningkatkan kinerja guru sebesar 0,734. Koefisien regresi sebesar 0,211 menyatakan bahwa setiap penambahan komitmen organisasi sebesar 0,211 akan meningkatkan kinerja guru sebesar 0,211 . Koefisien regresi sebesar $-0,185$ menyatakan bahwa setiap penurunan lingkungan fisik sebesar -0,185 akan meningkatkan kinerja guru sebesar 0,185. Hasil penghitungan koefisien korelasi dapat dilihat pada Tabel 9.

Berdasarkan Tabel 9 diketahui koefisien korelasi servant leadership dengan kinerja guru sebesar 0,686. koefisien korelasi komitmen organisasi dengan kinerja guru sebesar 0,511 dan koefisien korelasi lingkungan fisik dengan kinerja guru sebesar 0,501. 
Tabel 9. Koefisien Korelasi

\begin{tabular}{llcccc}
\hline & & $\begin{array}{c}\text { Kinerja } \\
\text { Guru }\end{array}$ & $\begin{array}{c}\text { Servant } \\
\text { leadership }\end{array}$ & $\begin{array}{c}\text { Komitmen } \\
\text { Organisasi }\end{array}$ & Lingkungan Fisik \\
\hline \multirow{3}{*}{ Pearson } & Kinerja Guru & 1.000 & .686 & .511 & .501 \\
Correlation & Servant leadership & .686 & 1.000 & .441 & .798 \\
& Komitmen Organisasi & .511 & .441 & 1.000 & .410 \\
& Lingkungan Fisik & .201 & .798 & .410 & 1.000 \\
& Kinerja Guru &. & .000 & .000 & .000 \\
\multirow{3}{*}{ Sig. (1-tailed) } & Servant leadership & .000 &. & .000 & .000 \\
& Komitmen Organisasi & .000 & .000 &. & .000 \\
& Lingkungan Fisik & .000 & .000 & .000 &. \\
& Kinerja Guru & 63 & 63 & 63 & 63 \\
& Servant leadership & 63 & 63 & 63 & 63 \\
& Komitmen Organisasi & 63 & 63 & 63 & 63 \\
& Lingkungan Fisik & 63 & 63 & 63 & 63 \\
\hline
\end{tabular}

Pengujian hipotesis secara parsial dihasilkan perhitungan sebagai berikut: $\mathrm{H}_{1}$ : Pengaruh yang positif dan signifikan servant leadership, komitmen organisasi dan lingkungan fisik secara bersama-sama terhadap kinerja guru. Hipotesis yang diuji:

$$
\begin{gathered}
H_{0}: \beta_{y 1}=\beta_{y 2}=\beta_{y 3}=0 \\
H_{1}: \beta_{y 1} \neq 0 \text { atau } \beta_{y 3} \neq 0
\end{gathered}
$$

Berarti bahwa $\mathrm{H}_{0}$ : Tidak terdapat pengaruh yang positif dan signifikan ervant leadership, komitmen organisasi, dan lingkungan fisik secara bersama-sama terhadap kinerja guru. $\mathrm{H}_{1}$ : Terdapat pengaruh yang positif dan signifikan servant leadership, komitmen organisasi, dan lingkungan fisik secara bersama-sama terhadap kinerja guru. Dari Tabel 7 dapat dinyatakan bahwa terdapat pengaruh yang signifikan servant leadership, komitmen organisasi, dan lingkungan fisik secara bersama-sama terhadap kinerja guru. Hal ini dibuktikan dengan perolehan nilai Sig. $0,000<0,05$ dan $F_{h}=22,618$. Berdasarkan hasil tersebut maka dapat dilakukan pengujian hipotesis secara parsial.

$\mathrm{H}_{2}$ : Pengaruh yang positif dan signifikan servant leadership terhadap Kinerja Guru. Hipotesis yang diuji:

$$
\begin{aligned}
& H_{0}: \beta_{y 1}=0 \\
& H_{1}: \beta_{y 1} \neq 0
\end{aligned}
$$

Berarti bahwa $\mathrm{H}_{0}$ : Tidak terdapat pengaruh yang positif dan signifikan servant leadership terhadap kinerja guru. $\mathrm{H}_{1}$ : Terdapat pengaruh yang positif dan signifikan servant leadership terhadap kinerja guru. Dari Tabel 8 dapat dinyatakan bahwa terdapat pengaruh yang positif dan signifikan servant leadership terhadap kinerja guru. Hal ini dibuktikan dengan perolehan nilai Sig. $0,000<0,05$ dan $t_{h}=4,665$. Adapun kontribusi variabel servant leadership terhadap kinerja guru adalah:

$$
\begin{gathered}
\mathrm{KD}=\text { Nilai } \beta_{x 1 y} \times \text { Nilai Korelasi Pasialnya }\left(r_{x 1 y}\right) \times 100 \% \\
\mathrm{KD}=0,702 \times 0,686 \times 100 \%=48,16 \%
\end{gathered}
$$

Dari hasil perhitungan tersebut dapat dinyatakan bahwa kontribusi servant leadership dalam meningkatkan kinerja guru sebesar $48,16 \% . \mathrm{H}_{3}$ : Pengaruh yang positif dan signifikan komitmen organisasi terhadap kinerja guru. Hipotesis yang diuji:

$$
\begin{aligned}
& H_{0}: \beta_{y 2}=0 \\
& H_{1}: \beta_{y 2} \neq 0
\end{aligned}
$$


Berarti bahwa $\mathrm{H}_{0}$ : Tidak terdapat pengaruh yang signifikan komitmen organisasi terhadap kinerja guru. $\mathrm{H}_{1}$ : Terdapat pengaruh yang signifikan komitmen organisasi terhadap kinerja guru. Dari Tabel 8 dapat dinyatakan bahwa terdapat pengaruh yang positif dan signifikan komitmen organisasi terhadap kinerja guru. Hal ini dibuktikan dengan perolehan nilai Sig. $0,004<0,05$ dan $t_{h}=3,370$. Adapun kontribusi variabel komitmen organisasi terhadap kinerja guru adalah:

$$
\begin{gathered}
\mathrm{KD}=\text { Nilai } \beta_{x 2 y} \times \text { Nilai Korelasi Pasialnya }\left(r_{x 2 y}\right) \times 100 \% \\
\mathrm{KD}=0,472 \times 0,511 \times 100 \%=24,11 \%
\end{gathered}
$$

Dari hasil perhitungan tersebut dapat dinyatakan bahwa kontribusi komitmen organisasi dalam meningkatkan kinerja guru sebesar $24,11 \%$. $\mathrm{H}_{4}$ : Pengaruh yang positif dan signifikan lingkungan fisik terhadap kinerja guru. Hipotesis yang diuji:

$$
\begin{aligned}
& H_{1}: \beta_{y 3}=0 \\
& H_{1}: \beta_{y 3} \neq 0
\end{aligned}
$$

Berarti bahwa $\mathrm{H}_{0}$ : Tidak terdapat pengaruh yang positif dan signifikan lingkungan fisik terhadap kinerja guru. $\mathrm{H}_{1}$ : Terdapat pengaruh yang positif dan signifikan lingkungan fisik terhadap kinerja guru. Dari Tabel 8 dapat dinyatakan bahwa tidak terdapat pengaruh yang positif dan signifikan lingkungan fisik terhadap kinerja guru. Hal ini dibuktikan dengan perolehan nilai Sig. $0,253>0,05$ dan $t_{h}=-1,154$. Adapun kontribusi variabel lingkungan fisik terhadap kinerja guru adalah:

$$
\begin{gathered}
\mathrm{KD}=\text { Nilai } \beta_{x 2 y} \times \text { Nilai Korelasi Pasialnya }\left(r_{x 2 y}\right) \times 100 \% \\
\mathrm{KD}=-0,171 \times 0,201 \times 100 \%=-3,43 \%
\end{gathered}
$$

Dari hasil perhitungan di atas dapat dinyatakan bahwa kontribusi komitmen fisik dalam menurunkan kinerja guru sebesar $-3,43 \%$.

Pembahasan

Hasil penghitungan pengujian hipotesis $\mathrm{H}_{1}$ yang berbunyi servant leadership, komitmen organisasi dan lingkungan fisik secara bersama-sama mempengaruhi kinerja guru SMK terbukti positif dan signifikan. Kontribusi seluruh variabel bebas tersebut memiliki nilai yang cukup tinggi, yaitu lebih dari 50\%. Hasil ini melengkapi hasil penelitian Arianto (2013) dan Purwoko (2018) bahwa servant leadership $\left(\mathrm{X}_{1}\right)$, komitmen organisasi $\left(\mathrm{X}_{2}\right)$ dan lingkungan fisik $\left(\mathrm{X}_{2}\right)$ berpengaruh positif dan signifikan terhadap kinerja guru. Para pemimpin yang sukses memberikan makna dan relevansi kepada bawahan yang melaksanakan tugas (Cheng \& Szeto, 2016). Pemimpin memberikan fokus, arah, dan jaminan bagi para bawahannya untuk selalu menjadi yang terdepan dalam menjalankan roda organisasi (Kale \& Özdelen, 2014). Begitu pula dengan kepemimpinan seorang kepala sekolah harus dapat meningkatkan kinerja guru dan sesuai harapan dari siswa dan orangtua murid. Kepemimpinan dengan pelayanan menjadikan bawahan dan pelanggan sebagai pelanggan yang harus selalu dilayani dengan baik (Salam \& Kewo, 2017).

Kepala sekolah yang menganut servant leadership akan selalu mengedepankan kepentingan pihak terkait yang dalam hal ini guru, pegawai dan tentu saja peserta didik (Liden, Wayne, Zhao, \& Henderson., 2008). Kepala sekolah akan selalu mempertimbangkan untuk memahami orang lain, mendengarkan dengan penuh perhatian kepada orang lain, berusaha memahami rekan kerja dan mampu berempati dengan orang lain, mampu menciptakan penyembuhan emosional, kesadaran untuk memahami isu-isu yang berkembang, melihat situasi dari posisi yang seimbang, meyakinkan orang lain daripada memaksa kepatuhan, visioner teliti dalam memahami pelajaran dari masa lalu, realitas saat ini, dan kemungkinan konsekuensi dari keputusan untuk masa depan, keterbukaan, komitmen untuk pertumbuhan dan membangun komunitas (Greasley \& Bocârnea, 2014; Mittal \& Dorfman, 2012).

Komitmen organisasi menjadikan guru akan lebih berkeingan untuk mengabdikan dirinya di sekolah (Jo, 2014). Guru yang memiliki komitmen tinggi cenderung akan bekerja dengan optimal dan memiliki etos kerja yang tinggi. Guru yang memiliki komitmen tinggi dalam bekerja akan 
menampilkan prilaku dan sikap kerja dari dalam hati. Guru akan menganggap mengajar di sekolah bukan sebagai kewajiban, akan tetapi suatu panggilan hati (Choi \& Tang, 2009). Guru yang komitmen juga akan lebih setiap dan loyal terhadap sekolah (Chesnut, 2017). Guru yang telah mencerminkan sikap berkomitmen akan melaksanakan tugas dan tanggungjawab dengan baik dan cepat (Mohammadtaheri, 2011). Guru akan mengajar dengan maksimal sesuai dengan prosedur dan standar yang telah ditetapkan (Al-Mahdy, Emam, \& Hallinger, 2018). Hal inilah yang menyebabkan akan mempengaruhi kinerja. Guru akan lebih maksimal, disiplin dan memenuhi standar kinerja guru professional jika memiliki komitmen yang tinggi (Mărgăriţoiu, 2015). Sebaliknya, jika guru memiliki komitmen yang rendah dapat menurunkan kinerja dan faktor lain yang terkait dengan performa guru.

Lingkungan kerja fisik adalah tempat atau ruangan dan fasilitas dimana seseorang mengadakan aktifitas serta suasana interaksi yang nyaman dan menyenangkan diantara orang-orang yang ada dalam organisasi (Smantser \& Ignatovitch, 2015). Lingkungan fisik yang nyaman dan menyenangkan akan mendukung guru dalam melaksanakan tugas pekerjaan yang baik bagi setiap orang. Lingkungan fisik yang berupa ruang kerja, fasilitas kerja, penerangan, udara, dan ketersediaan sarana dan prasarana dapat menjadi pemicu kinerja yang baik (Carlisle, Bhanugopan, \& D'Netto, 2019). Berdasarkan deskripsi teori bahwa lingkungan fisik yang kondusif sangat diperlukan untuk mewujudkan kinerja yang optimal (Gibson, Ivancevich, Donnelly, \& Konopaske, 2012). Kondisi lingkungan yang sirkulasi udaranya baik, fasilitas kerja tersedia, penerangan ruangan memadai akan dapat membuat para guru bekerja dengan nyaman (Luthans, 2011). Selain itu suasana kerja yang kondusif, hubungan atasan dan bawahan terjalin harmonis, hubungan harmonis antara para pegawai akan membuat para pegawai bekerja dengan tenang, dengan demikian akan menghasilkan pekerjaan optimal (Schermerhorn et al., 2010).

Dengan demikian dapat disimpulkan jika dalam setiap organisasi termasuk sekolah mengimplementasikan servant leadership, komitmen organisasi guru yang tinggi dan lingkungan fisik akan mempengaruhi kinerja guru di SMK. Hasil pengujian hipotesis $\mathrm{H}_{2}$ servant leadership $\left(\mathrm{X}_{1}\right)$ berpengaruh terhadap kinerja guru (Y) terbukti positif dan signifikan. Artinya, servant leadership yang tinggi akan meningkatkan kinerja guru siswa SMK Negeri di Jakarta Timur. Kontribusi langsung yang diberikan servant leadership paling tinggi dibanding variabel bebas lainnya dalam penelitian ini, yaitu 48,16\%. Koefisien korelasi yang dihasilkan juga yang tertinggi sebesar 0,686 yang berarti kuat. Hasil penelitian ini menyempurnakan hasil penelitian lain yang menyimpulkan servant leadership berpengaruh positif dan signifikan terhadap kinerja guru (Liden, Wayne, Zhao, \& Henderson, 2008; Salam \& Kewo, 2017).

Kinerja guru adalah hasil kerja yang dapat dicapai guru atau sekelompok guru dalam suatu sekolah sesuai dengan hasil yang diharapkan dalam rangka mencapai tujuan pendidikan dalam priode waktu tertentu (Prasetyono, Abdillah, \& Fitria, 2018). Pemimpin dengan kualitas prilaku kepemimpinan yang tinggi dalam melibatkan bawahan untuk pengambilan keputusan dan mendorong bawahan untuk meningkatkan prestasi kerja (Yusuf, 2017). Pemimpin juga diwajibkan mengarahkan bawahan mencapai tujuan organisasi dalam menunjukkan kepercayaan dan komitmen dalam menjalankan tugas (Cheng \& Szeto, 2016). Pemimpin akan mendorong bawahan melaksanakan tugas kewajibannya dengan taat pada aturan, bertanggung jawab, jujur, disiplin, mempunyai prakarsa, dapat bekerja sama, dan dapat diandalkan (Zuhry \& Sugiyarti, 2018).

Pengarahan yang dilakukan pemimpin dengan memberikan instruksi yang jelas, fokus kepada tujuan organisasi dan dengan dorongan yang positif dapat membuat bawahan akan berusaha maksimal dalam bekerja (Beardwell, Holden, \& Claydon, 2004). Hal inilah yang dapat diwujudkan dengan salah satu caranya menganut gaya kepemimpinan melayani. Gaya kepemimpinan servant leadership merupakan model kepemimpinan yang memiliki kesesuaian dengan nilai-nilai pendidikan (Salam \& Kewo, 2017). Pokok fikiran yang mendasari servant leadership menekankan pada upaya memberdayakan, memiliki unsur yang unik mengembangkan keberadaan seluruh anggota, pengikut atau orang yang dipimpin (Mittal \& Dorfman, 2012).

Hal inilah yang membedakan dengan jenis kepemimpinan lainnya bahwa servant leadership memiliki karakteristik: 1.) Komponen moral, artinya moral menjadi bagian yang menjadi satu kesatuan sebagai identitas pemimpin yang ditularkan kepada pengikutnya; 2.) Fokus terhadap layanan kepada pengikut, artinya pemimpin memberi perhatian bagi perbaikan, peningkatan dan pencapaian 
kinerja pribadi bawahan dan bukan sekedar untuk kepentingan organisasi apalagi kepentingan pribadi; 3.) Perhatian kepada kesuksesan semua pihak terkait, artinya seorang pemimpin memandang keberhasilan organisasi tak lepas dari kerja keras segala komponen internal maupun eksternal yang terkait dengan organisasi seperti: karyawan, pelanggan, mitra usaha maupun masyarakat; dan 4.) Refleksi diri, artinya seorang pemimpin menghindari profil pemimpin yang angkuh. Pemimpin yang mengusung model servant leadership memberi keterbukaan untuk segenap anggotanya maupun organisasi yang dipimpinnya berpartisipasi aktif dan kreatif serta membangkitkan motivasi yang besar bagi pegawainya untuk bekerja serta melibatkan hati mereka (Hsiao, Lee, \& Chen, 2015).

Nilai-nilai elemen inti dari servant leadership didasarkan pada nilai kerendahan hati dan menghormati orang lain dengan perhatian yang berfokus pada kepercayaan, penghargaan pada yang lain dan pemberdayaan (Salam \& Kewo, 2017), sehingga dapat disimpulkan bahwa semakin tinggi servant leadership yang dirasakan oleh para guru berakibat kepada semakin meningkatnya kinerja guru. Hasil pengujian hipotesis $\mathrm{H}_{3}$ didapatkan hasil komitmen organisasi berpengaruh positif dan signifikan terhadap kinerja guru SMK Negeri di Jakarta Timur. Hal ini berartinya, komitmen organisasi yang tinggi akan meningkatkan kinerja Guru SMK Negeri di Jakarta Timur. Kontribusi yang dihasilkan oleh variabel komitmen dalam penelitian ini meskipun tidak cukup besar yaitu 24,11\% akan tetapi dapat menjadikan pertimbangan bagi para pemimpin sekolah untuk selalu memperhatikan komitmen guru. Hasil penelitian ini menyempurnakan hasil penelitian lain yang mendapatkan kesimpulan komitmen organisasi memiliki pengaruh positif dan signifikan terhadap kinerja guru (Jo, 2014; Chesnut, 2017; Liu \& Werblow, 2019; Purwoko, 2018).

Berdasarkan deskripsi teori komitmen organisasi adalah kemauan yang kuat dari individu untuk tetap berada, bekerja, dan rasa memiliki pekerjaan di dalam organisasi (Breig, 2019). Guru yang menunjukkan komitmen organisasi akan memiliki keinginan untuk tetap terikat dan loyal baik secara emosional maupun psikologis terhadap sekolah (Choi \& Tang, 2009). Hal ini tercermin pada perasaan bangga dan loyal terhadap sekolah serta memiliki keinginan untuk tetap menjadi bagian organisasi atas dasar pertimbangan untung rugi. Perhitungan tersebut melihat kepada keuntungan untuk tetap bekerja dalam organisasi dan memperhitungkan kerugian jika meninggalkan organisasi (Karsli \& Iskender, 2009). Refleksi perasaan akan tanggung jawab seseorang untuk tetap menjadi bagian organisasi dengan memiliki kemauan kerja, dan tanggung jawab memajukan organisasi menunjuk pada komitmen kontinyu dan normatif (Mohammadtaheri, 2011).

Kesediaan individu untuk menyumbangkan tenaganya bagi tercapainya tujuan organisasi juga dipengaruhi secara signifikan oleh bentuk komitmen terhadap organisasi (Klassen \& Chiu, 2011). Seperti komitmen efektif yang lebih banyak terkait dengan pengalaman dalam pekerjaan yang dapat memuaskan kebutuhan individu secara psikologis, sehingga mereka merasa nyaman dan kompeten dalam menjalankan tugas pekerjaannya (Huang, 2011). Kinerja individu pada dasarnya merupakan efektivitas perorangan. Bila setiap anggota organisasi terkoordinir dalam melaksanakan tugas dan pekerjaan masing-masing dengan baik, kinerja secara keseluruhan akan timbul (Mărgăriţoiu, 2015). Pelaksanaan koordinasi diperlukan komitmen masing-masing dari para bawahan untuk melaksanakan dan menyelaraskan berbagai kegiatan mencapai tujuan yang telah ditetapkan, dalam kaitan dengan kinerja (Cheasakul \& Varma, 2016). Berdasarkan deskripsi teori kinerja adalah adalah prosedur atau cara tindakan kerja yang dilakukan oleh seseorang dalam melaksanakan tugas dan pekerjaannya yang dilakukan secara tepat dan sesuai dengan prosedur yang ditentukan yang diukur dan diperoleh (Khotimah, Gagah, \& Hashiolan, 2017).

Kinerja guru tidak akan terlepas dari komitmen dari masing-masing guru untuk mencapai tujuan dalam proses pendidikan (Rahawarin \& Arikunto, 2015). Guru yang memiliki komitmen tinggi dalam bekerja akan memenuhi target kerja yang diberikan karena kinerja ditekankan pada perhatian pada kesesuaian hasil yang dicapai sekolah dengan tujuan yang akan dicapai (Rahawarin \& Arikunto, 2015). Hasil pengujian hipotesis $\mathrm{H}_{4}$ dapat disimpulkan bahwa lingkungan fisik tidak memiliki pengaruh dan tidak signifikan terhadap kinerja guru SMKN di Jakarta Timur. Hasil penelitian ini sesuai dengan hasil penelitian lain yang menyimpulkan lingkungan kerja fisik memiliki pengaruh positif dan signifikan terhadap kinerja guru (Arianto, 2013; Jamali \& Prasojo, 2013). Temuan ini makin menciptakan keyakinan bahwa terdapat perbedaan yang mendasar antara lingkungan kerja di sekolah dengan lingkungan kerja di perkantoran karena jika merujuk kepada penelitian Hanafi dan Yohana (2017); Utami (2010); dan Vijaya dan Sriathi (2015), kesimpulannya 
mengatakan bahwa lingkungan kerja fisik dan non fisik berpengaruh positif dan signifikan terhadap kinerja pegawai penelitian diinstansi perkantoran.

Jika diuraikan secara mendalam lingkungan kerja memiliki pengaruh tidak langsung terhadap stress kerja pegawai (Foley \& Murphy, 2015). Variabel yang menjadi perantara (intervening) dalam penelitian tersebut adalah peranan individu. Sedangkan hasil penelitian lain menyatakan lingkungan kerja guru menjadi variabel intervening fasilitas sarana dan prasarana terhadap kinerja guru (Toom, Pietarinen, Soini, \& Pyhältö, 2017). Hasil penelitian berikutnya menunjukkan jika lingkungan kerja guru mempengaruhi motivasi dan komitmen guru dalam bekerja (Fernet, Trépanier, Austin, \& Levesque-Côté, 2016). Berdasarkan beberapa literatur tersebut dapat diasumsikan lingkungan kerja tidak berpengaruh secara langsung akan tetapi dalam menjadi variabel intervening untuk mempengaruhi kinerja guru di sekolah. Lingkungan fisik merupakan bagian dari iklim organisasi yang memberikan pengaruh pada organisasi (Schermerhorn, Hunt, Osborn, \& UhlBien, 2010). Lingkungan fisik tidak terlepas dari pengaruh lingkungan internal dan eksternal karena organisasi sebagai suatu sistem akan selalu berinteraksi dengan lingkungannya (Anderson, Ones, Sinangil, \& Viswesvaran, 2012). Lingkungan fisik suatu organisasi secara tidak langsung dapat mempengaruhi kinerja jika lingkungan fisik tersebut sungguh-sungguh bersentuhan langsung dengan pegawai dengan frekuensi yang tinggi (Gibson, Ivancevich, Donnelly, \& Konopaske, 2012).

Seorang guru yang bekerja di sekolah dengan suasana atau lingkungan fisik yang aman, nyaman, menyenangkan, akan mendukung untuk bekerja mencapai apa yang menjadi tujuan pendidikan (Adib-Hajbaghery \& Kamrava, 2019). Sebaliknya apabila tidak tercipta lingkungan fisik yang aman, nyaman dan menyenangkan, dapat diduga bahwa situasi organisasi tersebut sangat tidak kondusif, maka hubungan personal antar guru tidak akan berjalan dan guru akan sulit bekerja dalam tim secara efektif. Lingkungan fisik yang baik, menyenangkan dengan segala fasilitas kerja dapat memotivasi seluruh guru melakukan suatu pekerjaan dengan sukarela dan sepenuh hati sehingga kinerja semakin meningkat (Prilop, Weber, \& Kleinknecht, 2019). Hal ini mengakibatkan guru lebih termotivasi untuk bekerja dengan baik, hubungan antar pribadi, pekerja, hubungan dengan masyarakat disekitar tempat bekerja terjalin baik pula. Suasana yang memberikan rasa aman dan nyaman dalam bekerja menjadikan guru guru lebih termotivasi untuk meningkatkan kinerja (Smantser \& Ignatovitch, 2015). Namun jika lingkungan fisik yang terjadi sebaliknya dapat menurunkan motivasi guru dalam bekerja. Semakin mendukung lingkungan fisik yang ada (sarana prasarana, administrasi, dan tempat kerja), maka semakin besar kemungkinan seorang guru akan termotivasi dalam bekerja.

\section{SIMPULAN}

Terdapat pengaruh yang signifikan servant leadership, komitmen organisasi, dan lingkungan kerja fisik secara bersama-sama terhadap kinerja guru SMK Negeri di Jakarta Timur. Penelitian dilakukan pada 3 Sekolah Menengah Kejuruan Negeri di Kecamatan Cipayung Jakarta Timur, yaitu 1.) SMK Negeri 46 yang beralamat di Jl. Cipinang Pulo No .19, Cipinang Besar Utara, Jatinegara, Jakarta Timur; 2.) SMK Negeri 50 yang beralamat di Jl. Cipinang Muara I No. 4, Cipinang Muara, Jatinegara, Jakarta Timur; dan 3.) SMK Negeri 26 yang beralamat di Jl. Balai Pustaka Baru I, Rawamangun, Pulo Gadung, Jakarta Timur. Terdapat pengaruh yang signifikan servant leadership terhadap kinerja guru SMK Negeri di Jakarta Timur. Terdapat pengaruh yang signifikan komitmen organisasi terhadap kinerja guru SMK Negeri di Jakarta Timur. Tidak terdapat pengaruh yang positif dan signifikan lingkungan fisik terhadap kinerja guru SMK Negeri di Jakarta Timur. Berdasarkan kesimpulan tersebut penulis mengajukan saran sebagai berikut: servant leadership merupakan hal sangat penting dalam menentukan kinerja seorang guru, sehingga seorang kepala sekolah perlu mulai mengadaptasi gaya kepemimpinan servant leadership yang terbukti dalam penelitian ini memberikan kontribusi paling tinggi diban-dingkan variabel bebas lain. Kemudian, guru harus berusaha mandiri untuk dapat meningkatkan kinerjanya terutama dalam hal pengajaran. Terakhir, dilakukan penelitian lanjutan mengenai analisis lingkungan kerja fisik di sekolah karena temuan dalam penelitian ini tidak signifikan akan tetapi jika merujuk kepada literatur lain mengenai lingkungan kerja di perkantoran terdapat pengaruh positif dan signifkan. 


\section{DAFTAR PUSTAKA}

Adib-Hajbaghery, M., \& Kamrava, Z. (2019). Iranian teachers' knowledge about first aid in the school environment. Chinese Journal of Traumatology, 22(4), 240-245. doi: https://doi.org/10.1016/j.cjtee.2019.02.003

Al-Mahdy, Y. F. H., Emam, M. M., \& Hallinger, P. (2018). Assessing the contribution of principal instructional leadership and collective teacher efficacy to teacher commitment in Oman. Teaching and Teacher Education, 69, 191-201. doi: https://doi.org/10.1016/j.tate.2017.10.007

Anderson, N., Ones, D. S., Sinangil, H. K., \& Viswesvaran, C. (2012). Handbook of Industrial, Work \& Organizational Psychology (Vol. 2). Sage Publication doi: https://doi.org/10.4135/9781848608368.n11

Arianto, D. A. N. (2013). Pengaruh kedisiplinan, lingkungan kerja dan budaya kerja terhadap kinerja tenaga pengajar. Jurnal Economia, 9(2), 191-200. doi: https://doi.org/10.21831/economia.v9i2.1809

Beardwell, I., Holden, L., \& Claydon, T. (2004). Human resource management: A contemporary approach ( $4^{\text {th }}$ ed.). England: Pearson Education Limited. Retrieved from http://117.3.71.125:8080/dspace/bitstream/DHKTDN/6245/1/Human\%20resource\%20man agement $\% 20 \mathrm{~A} \% 20$ contemporary $\% 20$ approach.3085.pdf

Breig, Z. (2019). Endogenous and exogenous commitment. Economics Letters, 183, 18577. doi: https://doi.org/10.1016/j.econlet.2019.108577

Carlisle, J., Bhanugopan, R., \& D’Netto, B. (2019). Enhancing task performance through effective training: The mediating role of work environment and moderating effect of non-mandatory training. Journal of Business Research, 104(2018), 340-349. doi: https://doi.org/10.1016/j.jbusres.2019.07.033

Cheasakul, U., \& Varma, P. (2016). The influence of passion and empowerment on organizational citizenship behavior of teachers mediated by organizational commitment. Contaduria $y$ Administracion, 61(3), 422-440. doi: https://doi.org/10.1016/j.cya.2016.04.003

Cheng, A. Y. N., \& Szeto, E. (2016). Teacher leadership development and principal facilitation: Novice teachers' perspectives. Teaching and Teacher Education, 58, 140-148. doi: https://doi.org/10.1016/j.tate.2016.05.003

Chesnut, S. R. (2017). On the measurement of preservice teacher commitment: Examining the relationship between four operational definitions and self-efficacy beliefs. Teaching and Teacher Education, 68, 170-180. doi: https://doi.org/10.1016/j.tate.2017.09.003

Choi, P. L., \& Tang, S. Y. F. (2009). Teacher commitment trends: Cases of Hong Kong teachers from 1997 to 2007. Teaching and Teacher Education, 25(5), 767-777. doi: https://doi.org/10.1016/j.tate.2009.01.005

Darmawan, H. (2019, July 30). Kementrian perindustrian libatkan lembaga pendidikan Singapura tingkatkan kompetensi guru SMK. Tribun Bisnis. Retrieved from https://www.tribunnews.com/bisnis/2019/07/30/kementrian-perindustrian-libatkanlembaga-pendidikan-singapura-tngkatkan-kompetensi-guru-smk

Dattalo, P. (2008). Determining sample size: Balancing power, precision, and practicality. Oxford University Press. doi: https://doi.org/10.1017/CBO9781107415324.004

Eva, N., Robin, M., Sendjaya, S., van Dierendonck, D., \& Liden, R. C. (2019). Servant leadership: A systematic review and call for future research. The Leadership Quarterly, 30(1), 111-132. doi: https://doi.org/10.1016/j.leaqua.2018.07.004

Fernet, C., Trépanier, S. G., Austin, S., \& Levesque-Côté, J. (2016). Committed, inspiring, and healthy teachers: How do school environment and motivational factors facilitate optimal 
120 - Jurnal Akuntabilitas Manajemen Pendidikan

functioning at career start?. Teaching and Teacher Education, 59, 481-491. doi: https://doi.org/10.1016/j.tate.2016.07.019

Foley, C., \& Murphy, M. (2015). Burnout in Irish teachers: Investigating the role of individual differences, work environment and coping factors. Teaching and Teacher Education, 50, 46-55. doi: https://doi.org/10.1016/j.tate.2015.05.001

Gibson, J. L., Ivancevich, J. M., James H. Donnelly, J., \& Konopaske, R. (2012). Organizations behavior, structure, processes $\left(14^{\text {th }}\right.$ ed.). McGraw-Hill. Retreived from http://dl.motamem.org/organizations_behavior_structure.pdf

Gorard, S. (2004). Quantitative methods in social science. Continuum. doi: https://doi.org/10.1017/CBO9781107415324.004

Greasley, P. E., \& Bocârnea, M. C. (2014). The Relationship between personality type and the servant leadership characteristic of empowerment. Procedia-Social and Behavioral Sciences, 124, 11-19. doi: https://doi.org/10.1016/j.sbspro.2014.02.454

Hanafi, B. D., \& Yohana, C. (2017). Pengaruh motivasi, dan lingkungan kerja, terhadap kinerja karyawan, dengan kepuasan kerja sebagai variabel mediasi pada PT BNI Lifeinsurance. Jurnal Pendidikan Ekonomi Dan Bisnis (JPEB), 5(1), 72-89. doi: https://doi.org/10.21009/JPEB.005.1.6

Hasanah, D. S., Fattah, N., \& Prihatin, E. (2010). Pengaruh Pendidikan Latihan (Diklat) kepemimpinan guru dan iklim kerja terhadap kinerja guru sekolah dasar se Kecamatan Babakancikao Kabupaten Purwakarta. Jurnal Penelitian Pendidikan, 11(2), 90-105. Retrieved from http://jurnal.upi.edu/file/8-Dedeh_Sofia_Hasanah.pdf

Hsiao, C., Lee, Y., \& Chen, W. (2015). The effect of servant leadership on customer value cocreation : A cross-level analysis of key mediating roles. Tourism Management, 49, 45-57. doi: https://doi.org/10.1016/j.tourman.2015.02.012

Huang, T. M. (2011). The relationship between headmasters' leadership behaviour and teachers commitment in primary schools in the district of Sarikei, Sarawak. Procedia-Social and Behavioral Sciences, 29, 1725-1732. doi: https://doi.org/10.1016/j.sbspro.2011.11.418

Jamali, A., \& Prasojo, L. D. (2013). pengaruh kompetensi manajerial kepala sekolah, lingkungan, motivasi guru, terhadap prestasi siswa SMA Muhammadiyah Kota Yogyakarta. Jurnal Akuntabilitas Manajemen Pendidikan, 1(1), 8-21. doi: https://doi.org/10.21831/amp.v1i1.2309

Jo, S. H. (2014). Teacher commitment: Exploring associations with relationships and emotions. Teaching and Teacher Education, 43, 120-130. doi: https://doi.org/10.1016/j.tate.2014.07.004

Kale, M., \& Özdelen, E. (2014). The analysis of teacher leadership styles according to teachers' perceptions in primary schools. Procedia-Social and Behavioral Sciences, 152, 227-232. doi: https://doi.org/10.1016/j.sbspro.2014.09.185

Karsli, M. D., \& Iskender, H. (2009). To examine the effect of the motivation provided by the administration on the job satisfaction of teachers and their institutional commitment. Procedia-Social and Behavioral Sciences, 1(1), 2252-2257. doi: https://doi.org/10.1016/j.sbspro.2009.01.396

Kartowagiran, B. (2011). Kinerja guru profesional (guru pasca sertifikasi). Cakrawala Pendidikan, 30(3), 463-473. doi: https://doi.org/10.21831/cp.v3i3.4208

Khotimah, R., Gagah, E., \& Hashiolan, L. B. (2017). Pengaruh kepemimpinan, stres kerja, dan lingkungan kerja terhadap kinerja karyawan produksi di PT. Ungaran Sari Garment. Journal of Management, 3(3), 1-9. $\quad$ Retrieved from http://jurnal.unpand.ac.id/index.php/MS/article/view/858 
Klassen, R. M., \& Chiu, M. M. (2011). The occupational commitment and intention to quit of practicing and pre-service teachers: Influence of self-efficacy, job stress, and teaching context. Contemporary Educational Psychology, 36(2), 114-129. doi: https://doi.org/10.1016/j.cedpsych.2011.01.002

Liden, R. C., Wayne, S. J., Zhao, H., \& Henderson, D. (2008). Servant leadership : Development of a multidimensional measure and multi-level assessment. The Leadership Quarterly, 19, 161177. doi: https://doi.org/10.1016/j.leaqua.2008.01.006

Liu, Y., \& Werblow, J. (2019). The operation of distributed leadership and the relationship with organizational commitment and job satisfaction of principals and teachers: A multi-level model and meta-analysis using the 2013 TALIS data. International Journal of Educational Research, 96(May), 41-55. doi: https://doi.org/10.1016/j.ijer.2019.05.005

Luthans, F. (2011). Organizational behavior an evidence-based approach (12 ${ }^{\text {th }} \mathrm{ed}$.). New York: The McGraw-Hill Companies, Inc.

Mărgăriţoiu, A. (2015). Teachers' commitment from special-need schools - A Predictor of their Humanity and Loyalty. Procedia-Social and Behavioral Sciences, 203, 322-326. doi: https://doi.org/10.1016/j.sbspro.2015.08.302

Mittal, R., \& Dorfman, P. W. (2012). Servant leadership across cultures. Journal of World Business, 47(4), 555-570. doi: https://doi.org/10.1016/j.jwb.2012.01.009

Mohammadtaheri, N. (2011). The study of effective factors on the teachers' work commitment in High Schools. Procedia-Social and Behavioral Sciences, 29, 1524-1530. doi: https://doi.org/10.1016/j.sbspro.2011.11.393

Nasrun, N. (2016). Pengaruh kepemimpinan kepala sekolah terhadap motivasi kerja dan kinerja guru. ilmu pendidikan. Jurnal Kajian Teori Dan Praktik Kependidikan, 1(2), 63-70. doi: https://doi.org/10.17977/um027v1i22016p063

Pramana, A. G. K., \& Sudharma, I. N. (2013). Pengaruh kompensasi, lingkungan kerja fisik dan disiplin kerja terhadap kinerja karyawan. E-Jurnal Manajemen Universitas Udayana, 2(9), $1175-1188$. Retrieved

from https://ojs.unud.ac.id/index.php/Manajemen/article/download/5723/4544

Prasetyono, H., Abdillah, A., \& Fitria, D. (2018). Academic supervision toward teachers' performance through motivation as intervening variable. Journal of Education and Learning (EduLearn), 12(2), 188-197. doi: https://doi.org/10.11591/edulearn.v12i2.7324

Prilop, C. N., Weber, K. E., \& Kleinknecht, M. (2019). How digital reflection and feedback environments contribute to pre-service teachers' beliefs during a teaching practicum. Studies in Educational Evaluation, 62, 158-170. doi: https://doi.org/10.1016/j.stueduc.2019.06.005

Purwoko, S. (2018). Pengaruh kepemimpinan kepala sekolah, komitmen guru, disiplin kerja guru, dan budaya sekolah terhadap kinerja guru SMK. Jurnal Akuntabilitas Manajemen Pendidikan, 6(2), 149-162. doi: https://doi.org/10.1017/CBO9781107415324.004

Pusriawan, P., \& Soenarto, S. (2019). Employability skills of vocational school students in Palu City for entering the work world. Jurnal Pendidikan Vokasi, 9(1), 33-42. doi: https://doi.org/10.21831/jpv.v9i1.23351

Rahawarin, C., \& Arikunto, S. (2015). Pengaruh komunikasi, iklim organisasi dan gaya kepemimpinan transformasional kepala sekolah terhadap kinerja guru SMA. Jurnal Akuntabilitas Manajemen Pendidikan, 3(2), 173-188. doi: https://doi.org/http://dx.doi.org/10.21831/amp.v3i1.6275

Salam, A. A., \& Kewo, C. L. (2017). Servant leadership: model kepemimpinan kontemporer kepala sekolah. Jurnal Manajemen dan Supervisi Pendidikan, 2(1), 75-82. doi: https://doi.org/10.17977/um025v2i12017p075 
Schermerhorn, J. R., Hunt, J. G., Osborn, R. N., \& Uhl-Bien, M. (2010). Organizational behavior. Denvers: John Wiley \& Sons, Inc.

Singh, K. (2007). Quantitative social research methods. Los Angeles: SAGE Publications.

Sinha, S., \& Hanuscin, D. L. (2017). Development of teacher leadership identity: A multiple case study. Teaching and Teacher Education, 63, 356-371. doi: https://doi.org/10.1016/j.tate.2017.01.004

Smantser, A., \& Ignatovitch, E. (2015). Future teacher training for work in inclusive educational environment: Experimental study results. Procedia-Social and Behavioral Sciences, 214, 422-429. doi: https://doi.org/10.1016/j.sbspro.2015.11.699

Sumantri, R. F. (2012). Kompetensi pengelolaan pembelajaran, kecerdasan interpersonal, komitmen, dan kepuasan kerja guru smk. Jurnal Ilmu Pendidikan, 18(1), 30-35. doi: https://doi.org/10.17977/jip.v18i1.3380

Suriansyah, A. (2014). Hubungan budaya sekolah, komunikasi, dan komitmen kerja terhadap kinerja guru sekolah dasar negeri. Cakrawala Pendidikan, 23(3), 358-367. doi: https://doi.org/10.21831/cp.v3i3.2380

Susanto, H. (2012). Faktor-faktor yang mempengaruhi kinerja guru sekolah menengah kejuruan. Jurnal Pendidikan Vokasi, 2(2), 197-212. doi: https://doi.org/10.21831/jpv.v2i2.1028

Suwondo, D. I., \& Sutanto, E. M. (2015). Hubungan Lingkungan Kerja, Disiplin Kerja, Dan Kinerja Karyawan. Jurnal Manajemen Dan Kewirausahaan, 17(2), 135-144. doi: https://doi.org/10.9744/jmk.17.2.135

Tokhibin, T., \& Wuradji, W. (2013). Pengaruh kepemimpinan transformasional kepala sekolah, kompetensi, motivasi dan kedisiplinan guru terhadap kinerja guru SMK. Jurnal Akuntabilitas Manajemen Pendidikan, 1(2), 308-320. doi: https://doi.org/10.21831/amp.v1i2.2402

Toom, A., Pietarinen, J., Soini, T., \& Pyhältö, K. (2017). How does the learning environment in teacher education cultivate first year student teachers' sense of professional agency in the professional community?. Teaching and Teacher Education, 63, 126-136. doi: https://doi.org/10.1016/j.tate.2016.12.013

Utami, S. S. (2010). Pengaruh kepemimpinan, motivasi, komunikasi dan lingkungan kerja terhadap kinerja pegawai. Jurnal Manajemen Sumberdaya Manusia, 4(1), 58-67. Retrieved from http://ejurnal.unisri.ac.id/index.php/Manajemen/article/view/89/62

Vijaya, I. D. G. N. E. T., \& Sriathi, A. A. A. (2015). Pengaruh kepemimpinan transformasional, lingkungan kerja fisik dan kompensasi terhadap kinerja karyawan pada perusahaan cok konfeksi Denpasar. E-Jurnal Manajemen Unud, 4(7), 1771-1784. doi: https://doi.org/10.3997/2214-4609.201404048

Wahyu, A., \& Lantu, D. C. (2014). Servant leadership theory development \& measurement. Procedia-Social and Behavioral Sciences, 115, 387-393. doi: https://doi.org/10.1016/j.sbspro.2014.02.445

Warren, J. M., \& Hale, R. W. (2016). The influence of efficacy beliefs on teacher performance and student success: Implications for student support services. Journal of Rational-Emotive and Cognitive-Behavior Therapy, 34(3), 187-208. doi: https://doi.org/10.1007/s10942-016$\underline{0237-\mathrm{z}}$

Yusuf, Y. (2017). Hubungan kepemimpinan kepala sekolah dan pelayanan dengan kepuasan siswa. Jurnal Manajemen dan Supervisi Pendidikan, 2(1), 1-7. doi: https://doi.org/10.17977/um025v2i12017p001 
Zuhry, A. W \& Sugiyarti, G. (2018). Pengaruh gaya kepemimpinan, pendidikan dan pelathan struktural, dan komitmen organisasi terhadap kompetensi peserta. Jurnal Manajemen dan Supervisi Pendidikan, 3(1), 1-11. doi: http://dx.doi.org/10.17977/um025v3i12018p001 